\title{
Regional Educational Development Research in Sweden of Forty Years
}

\author{
Lena Bostrom \\ Department of Education \\ Mid Sweden University, Sweden
}

Received: Jan. 29, 2015 Accepted: March 11, 2015 Published: May 1, 2015

doi:10.5296/jse.v5i2.7197 URL: http://dx.doi.org/10.5296/jse.v5i2.7197

\begin{abstract}
In order to examine regional educational development in combination with school development in Sweden during the last 40 years, this paper presents the results of an integrative, systematic literature review. The study shows a sprawling result: a dozen regional projects mostly directed to higher education, little debate, mostly descriptive studies, weakly evaluated governmental educational initiatives, and hardly any research or debates ranging from preschool through the whole school system. However, the most important implication is the need for reanalysis of the values that permeate the entire school system and the community of life values in rural areas.
\end{abstract}

Keywords: Literature review, Regional educational development, School improvement, Sweden, Rural values 


\section{Introduction}

Two counties in Mid Sweden, Jämtland and Västernorrland, have identified regional educational problems. These counties have lower educational level and school achievements compared to other parts in Sweden (Skolverket, 2014) and have a relatively large proportion of an out-migration of well-educated individuals from the region (Statistiska centralbyrån, 2014). The national school results have, in some parts of the region, steadily declined for nine years; in other parts, they also need to be improved (Skolverket, 2014).

An effort to connect to regional educational development in the school context is the research project "The Best Regional Education Systems in the World" which is a partnership among the Mid Sweden University, companies and public sectors in Mid Sweden, and three selected schools in the region of Mid Sweden. The underlying assumption is that the regional educational system needs to contribute to the regions welfare and the intent behind the project is to make it possible for a region like Mid-Sweden to develop in a positive way for people, companies, and the public sector, which is also in line with Ambos and Schlegelmilch (2010), Florida (2002) and Olsson and Wiberg (2003). This study should also be viewed in light of the major role of institutions for growth and prosperity, where, in particular, the institutions' ability to change and adapt to new circumstances is of great importance. The institutional framework can lead to success, stagnation, or declines in the regions (North, 1990).

To contextualize that project, an integrative, systematic literature overview of the current debates and conclusions within regional educational development in Sweden is provided, including a consideration of the relationships among regions, education and success factors. Therefore, the aim of this sub-study in the project is to identify regional educational development research and regional school improvements across a variety of contexts of associated literature published between 1983 and 2013. For Nordic educational research, this is highly relevant because of problems with regional equality as well as expertise relocation and its repercussions on the entire education system (Dahlström, 1996; Svensson, 2006). First, to contextualize the findings of the review, this article provides an overview of the current debates and conclusions within regional educational development and school improvements internationally, including a consideration of the relationships among regions, education, and school improvements. Second, the method of the review is outlined. The integrative literature review has many benefits for the scholarly reviewer, including evaluating the strength of the scientific evidence, identifying gaps in current research, identifying the need for future research, bridging between related areas of work, identifying central issues in an area, generating a research question, identifying a theoretical or conceptual framework, and exploring which research methods have been used successfully. Third, a summary and discussion of the outcomes of the review are presented. This is structured around two levels of analysis of the review data: a general overview concerning the distribution, research foci, associated theoretical framework, methods, and design of the articles reviewed, followed by a thematic analysis of regional educational development research in relation to school improvements from a national perspective. 


\section{Previous Research}

The past decade may have witnessed considerable expansion and development within the field of regional educational research (From \&Olofsson, 2014). The importance of higher education for a region's growth has increasingly attracted international attention in many countries, such as Russia, Britain, Canada, Turkey, China, and Australia, and in all continents. If countries want to be globally competitive, regional innovation systems need to be strengthened. In order to achieve this, cooperation among higher educational institutions, public authorities, and the business sector becomes vital. Regional engagement, academic excellence, and research are complementary activities (Ambos \&Schlegermilch, 2010; Weibull\& Nilsson, 2010). In order to allow innovative efforts in peripheral regions to be as productive as they are in core areas, they need to be complemented by huge investments and human capital (Crescenzi, 2005). The role of human capital and the creative class as well as technology factors sharpen regional development. For regions to compete, evolve, and survive, education is crucial, and there are clear links between education and regional development (From \&Olofsson, 2013; Florida, Mellander, \&Stolarick, 2010). Also, a good education system, ranging from preschool through elementary school and high school to university level and postgraduate education, is vital to development. This mutual relationship is described by Hernandez and Goodson (2010) and Veugelers and Ziljstra (2010) and emphasizes that initiatives in the classroom or department are influenced by the surrounding context of the school, the district, and the nation. Of course, such initiatives are important not only from a regional perspective, but also from a national and international context. A further aspect is the concept of regional management, which seems to play an important role for regional headquarters to develop into dynamic competence centers (Ambos \& Schlegermilch, 2010).In Sweden, regional educational development, in corresponding with academic attention, is problematized and researched (e.g., Persson, 2003; Westerlund, Deiaco \& Johansson, 2005). This key question has to be asked of politicians: How can we make sense of current regional educational research and debates in order to navigate the research evidence to allow for critically informed decisions to be made about the influence of regional policy decisions?(Gullstrand \& Hammarlund, 2007). A key question for a practitioner teaching in school or higher education today could be as follows: How can we make sense of current regional educational research and debates in order to implement the results in teaching and courses? (Svensson, 2006a,b).

\section{Aim and Methods}

The aim of the study was to deepen the knowledge of previous research on regional educational development and school improvements in Sweden as well as to capture and describe the phenomenon of variation in different contexts. This study is based on an integrative and systematic literature review (SLR), inspired by Polit and Beck's(2008) model which provided a flow chart of the literature review and a qualitative, thematic, content analysis. Integrative literature reviews offer a means for researchers to search for and assess what is known about a particular topic with to the aim of finding a solution to a particular problem or suggesting directions for future research. It is described as being the broadest category of research reviews, combining the findings of a range of different research designs including those of 
qualitative and quantitative studies (Evans, 2008).

To analyze the contents of the various texts, a descriptive content analysis was performed. Content analysis means that the contents of the results of the studies were examined methodically and progressively while interpreting texts to find prevalent phenomena. The content analysis model is characterized by its identification of distinctive categories which are then narrowed down to even more specific categories. Traditional content analysis can be divided into three steps: selection of focus texts, encoding of the texts, and interpretation of the results (Auhiva, 2008). During the second step, problems can arise mainly with connotative interpretations, which require expertise and are best reviewed collaboratively. The situational context was taken into account, so the "maximum variation sampling" was achieved (Franzosi, 2008). Maintaining scientific integrity involves great attention to validity during the phase of the integrative review, and not defining the operational definitions too narrowly or too broadly. The reviewer must balance the definitions and methods review constantly during the research process. The integrative literature review has many benefits to the scholarly reviewer, such as identifying gaps in current research and a need for future research, bridging between related areas of work, and highlighting central issues in an area (Cooper, 1998). A thematic integrative study design was chosen to obtain a holistic understanding of the subject. This approach, in accordance with the method allows researchers to combine data from the theoretical literature as well as empirical literature (Whittemore \& Knafl, 2005 ) which also makes the analysis more complex and difficult. The purpose could also therefore be answered from a wider range of sources.

\subsection{Strategy and Inclusion Criteria}

Employing progressively detailed inclusion criteria, the systematic review of the literature involved multiple phases: an initial identification of potential studies via an advanced search of PRIMO ${ }^{1}$; subsequent screening of abstracts and titles; a review of 13 books, 4 book chapters, and 3 reports on the theme, and an in-depth review and theoretical analysis of 14 full articles. An automated advanced search of this database was conducted using increasingly refined search criteria to identify those potentially relevant studies for use in the review (see Figure 1).

\footnotetext{
${ }^{1}$ Primo is the discovery tool for Mid Sweden University, a single access point where one can find articles, books and journals that the library has procured - both print and digital full texts.
} 
Summery of Method of

\section{Review}

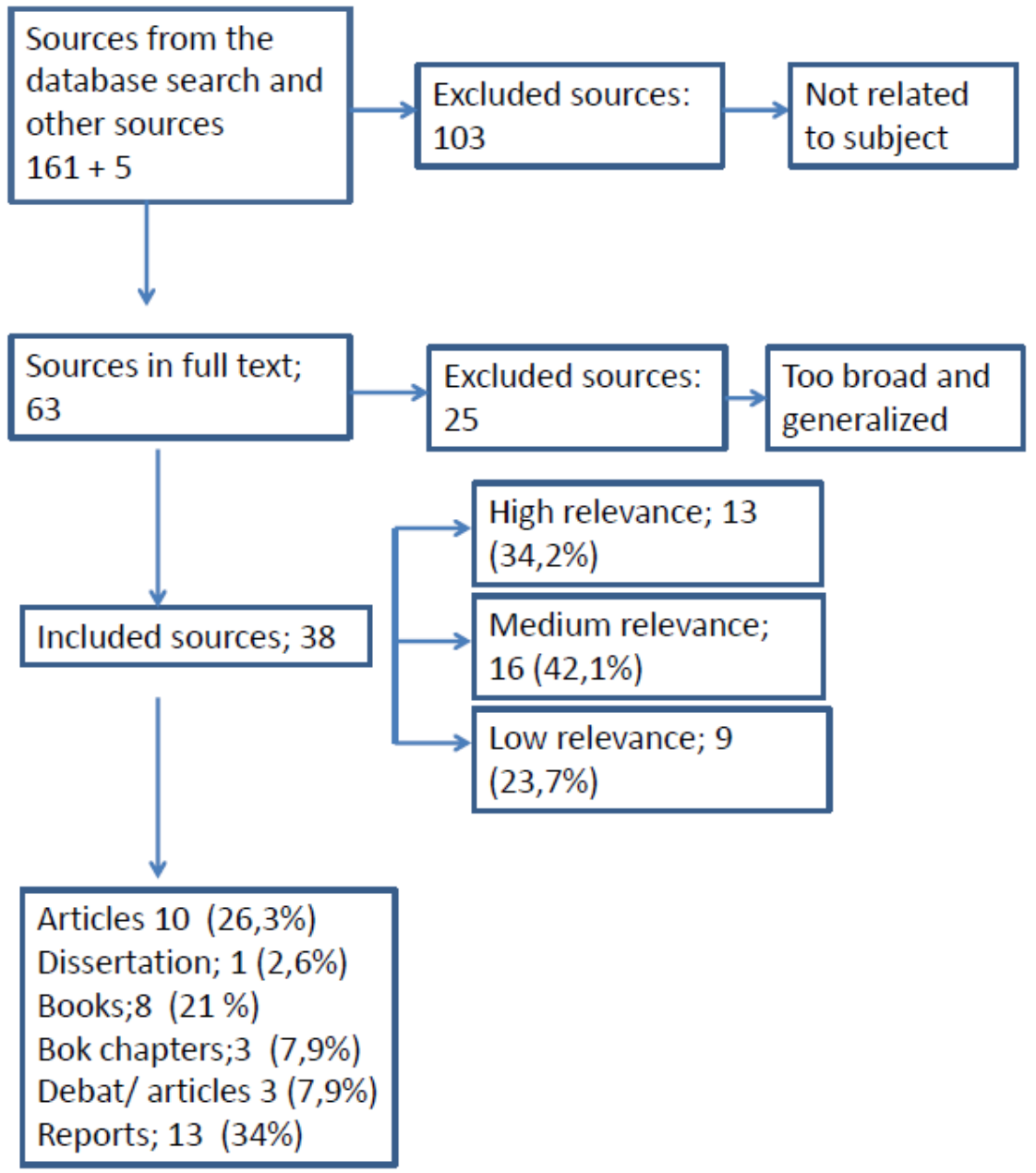

Figure 1. Summery of Method of Review

Keywords used were regional educational development*, school improvements*, school efficiency*, regional school development*, school effectiveness*, and Sweden* with different combinations - both the Swedish and English words. The literature search was limited to 1983-2013 and to publications written in English or Swedish. The limitations of these years was due to that the first text was recovered 1983 and the literature review was undertaken 2013.

The next phase of the review involved the retrieval and screening of the full articles. Using the more detailed information from each of the full articles, the inclusion criteria were reapplied. In addition to the original inclusion criteria, those full articles/texts that formed the initial in-depth review were also judged and selected on the basis of the extent to which they provided comprehensive accounts of different aspects of the nature, methodology, and findings of the study. Using the remaining 38 sources, a thematic analysis (Braun \& Clarke, 2006) of the data was then carried out to identify key themes occurring within the sources. The sources were reviewed and evaluated concerning content, scientific quality, and relevance. The assessment of the relevance of the articles was done in collaboration with 
members of the research team. Data processing, assessing quality, sorting, categorization, and examination of the items were made using assessment documentation through an thematic analysis (see Appendix I). Articles are presented in matrix (see Appendix II).

\section{Results and Analysis}

This section outlines the outcomes of the review. It is structured around two levels of analysis: 1) distribution of themes, years, methodological approaches, assessed relevance, sources and languages of the articles reviewed; and 2) followed by a thematic analysis and discussion of the data in relation to the nature and impact on regional educational development and school improvements.

\subsection{Distribution}

A total of 168 sources were included in the initial review; 103 of these were then excluded, leaving 63 full text sources for in-depth review. Further, 25 sources were excluded and regarded as irrelevant content for the study. Thus, 38 sources served as the basis for this literature review.

As shown in Appendix I (table 1), researchers found there were six themes in overlapping clusters. In all, $28.9 \%$ of these sources focused on different regional projects, $15.8 \%$ focused on different kinds of "mental images" for students in connection to regional development, $13.1 \%$ were debate articles, $10.5 \%$ focused on higher educational and research and for the theme of women, $7.9 \%$ focused on regional educational initiatives, $5.2 \%$ focused on both higher education (HE) and research and regional projects, $5.2 \%$ were a combination of HE and research and regional educational initiatives, and $2.6 \%$ were a combination of women and regional educational initiatives.

The reviewed sources had been published in 1986-2013. As we can see in Appendix I (table 2 ), the majority of the sources were published in the first decade of the millennium (2001-2010); not less than $68 \%$ of all texts were published these years. Regarding the different sources published, table 3 shows that $34.2 \%$ were reports, $26.3 \%$ were articles, $21 \%$ were books, $7.9 \%$ were book chapters or debate articles, and one was a thesis. The methodological approaches were overwhelmingly qualitative $(94.7 \%)$, and the same was true for the language, which was almost exclusively Swedish (92.1\%) (see table 4 and 6). The estimated contextual relevance in relation to the purpose of the study was as follows: $44.7 \%$ medium, $31.6 \%$ high, and $23.7 \%$ low (table 5). To determine contextual relevance the research team was used to inter-rater reliability tests to determine the strength of the determinations.

Efforts in regional educational development in Sweden were directed to adults, higher education, regional projects, and initiatives. Most of the sources were published in 20012010, which is natural as the major regional economic initiatives were implemented years before. Most studies are descriptive with qualitative approaches and written in Swedish. Only a quarter of the texts could be classified as research, which also has repercussions on the texts' relevance. The research texts were more highly scientifically valued. However, by using an integrative literature review, this study shows what is known about this topic and also provides a large variation sampling. 


\subsection{Thematic Analysis}

One dominant theme was regional projects, which, to some extent, overlapped with two other themes: regional education initiatives and higher education and research. In addition, three other themes - debate, women and mental images - could be discerned.

Regional projects. A dozen regional projects are described or/and evaluated in these forty years. Some examples are regional sustainable development for municipality population growth (Augustinsson \& Nilsson, 2005), regional efficiency and innovate production methods (Rylander, Ebbesson, Törn, \& Abbasian, 2010), regional vocational higher education programs (Fregidou -Malama \& Jakobson, 2008), research on regional and local development processes (FoU-Centrum i Söderhamn, 2005) and female entrepreneurship, equality, and inclusion (Lundgren, 2007).

Regional educational initiatives. Two educational projects reviewed governmental funding. Regional educational investments (RUS) received 120 million during 1988-1991 that were applicable to high school, adult education, and college collaborations (UḦ̈ Report, 1992, a, b, c). The conclusions are that entrenched and elaborate project proposals should be based on real regional needs, the funding was less than what municipalities were hoping for, and that referrals from RUS should have been clearer. Another education initiative was an allocation of 150 million Swedish Crowns (SEK) for collaboration between higher education and municipalities during 2002 -2004, (Westerlund et al. 2005; Unge \& Samverkansdelegationen, $2005 \mathrm{a}, \mathrm{b})$. Eighteen projects establishing new educational initiatives were described and evaluated. Results were new cooperation structures, increased coupling of regional and local development projects, strengthening of local learning centers, a raised level of education and human capital customized to local labor market needs, and the promotion of cooperation between different actors. However, the following was recommended:

Shall collaboration between the university and the community be a dynamic force in regional and national development; it must be built on both education and research, based on fixed resources and guided by a long-term strategy. (Westerlund, Enrico,\& Johansson, 2005, p. 76).

One Swedish region, Västra Götaland, had a prominent role in the literature review and involved education, research, regional development, and autonomy. There is a high correlation between knowledge about higher education in general, and a positive image of its activity, which provides a positive outlook for higher education among the general public. This region had no high level of regional identification (Nilsson, 2000), but the idea of a coherent and uniform education system where citizens, educators, and politicians are able to engage across school boundaries and ideological plank has this been an issue, so even it is important to engage in international affairs and build up external contacts.

Higher education and research. Universities and regions (also named the twins) have historically been mutually interactive regarding education and regional vitality (Olsson $\&$ Wiberg, 2003). The importance of higher education and research in all educational programs stimulates regional development (Weibull \& Nilsson, 2010). Universities have historically been associated with growth, but now there is a regional competition (regionalism), and new 
ideas about regional growth and new contextual analysis are needed:

... the presence of colleges and universities seem to be an almost necessary condition for regional economic growth, it is not a sufficient condition. Something else is also needed. The question is what (Olsson \& Wiberg, 2003, p. 31).

Universities, colleges, and research have expanded since the 1990s in Sweden as an important factor in times of increased operating environment dependency and increased global competition. Higher education institutions were expanded with great expectations about growth in the regions. However, it seems expectations were difficult to fulfill (Sörlin, 2000). As the knowledge society is characterized by spatial concentration, the strong regions have expanded while the weaker ones have decreased in size (Persson, 2003). Research and education have the most industrial effect in cities with more than one million inhabitants. When knowledge societies are formed, the coordination of several policies, a rich culture, and a rich local community life is important (Florida et al. 2010).

Debates, development, winding up, democracy, and entrepreneurship. In 1986, the role of education in economic and regional development had already been problematized by Östlund. The author recommended that educational initiatives would apply to all age groups (not just youth), that the local work would be so attractive that well-educated would stay there or move there. He also focused on the importance of good differentiation of labor, investment in higher education as a regional educational initiative and development resource, forms of collaboration between industries and universities, and investing in government or governmental agencies.

Regional partnerships could be seen as a threat or a realization of democracy (Hudson, 2001). Hudson asked what opportunities the new regional partnerships have to strengthen or weaken democracy in the context of the regional growth agreements. Quite similar questions were expressed by Bergström- Levander (2003) and Gullstrand and Hammarlund (2007). One consequence is that higher educational investments in rural areas weaken Sweden's growth. Another is that a county, which already has a highly educated workforce strengthen, thus its favorable age structure. Regional growth will be reflected in regions' education levels.

An open question regarding whether entrepreneurship education can contribute to the local community change and development was asked by Olofsson (2006). He described the promotion of entrepreneurship conducted in Västernorrlands County and wanted to create a discussion about entrepreneurship opportunities in rural areas (Olofsson, 2006).

Women. Women's situations were also a focus. Their position in the labor market and the education system was based on reports from the county administrative boards that were analyzed by Ericsson (1987). Traditionally, female occupations tended to become increasingly important for the women's labor market, and there were large regional variations in the labor force distribution on work requiring different skill levels. The differences were greater for women compared to men.

The efforts appeared to continue to have a bias towards the previously dominant working areas (Hammar \& Svensson, 2005). In the regional areas, women's participation and importance did not change, but a start of development at the local level could be discerned 
(2001-2005). These authors ask themselves where all the women had gone in regional development. The same question was asked by Hard (2007) - it was more specifically regarding how gender mainstreaming is integrated in regional growth policy. Women's ability to define and influence social and regional growth in different regions is severely limited, by issues such as meeting times and standard office hours and getting women appointed and called into leadership positions.

Another perspective of women in a male-dominated periphery and experiences from northern Scandinavia involved descriptions of young people's migration patterns from Troms County. The focus is on rural youth migration patterns. The periphery is dominated by male economies and recreational activities. Rural women are less visible, and their activities are not as valued as males' activities. Young men tend to follow in their fathers' footsteps, while young rural women break from the mother's life path. The young women in rural areas are breaking new ground by continuing in higher education. The young men at risk of being left behind become "losers" (Dahlström, 1996, p. 28).

Mental images. Mental images are another theme. There seems to be correlations between the children's statements about their future and the outcomes in middle age. Children with low and surprisingly high expectations (about 25\%) suffered from increased mortality, economic problems, and weak attachment to the labor market during middle age. Expectations may have been self-fulfilling prophecy, but the analysis also showed that the expectations mainly reflect background facts known to the children-e.g., childhood conditions, parents' characteristics, homeland possibilities, their own abilities and performance (Halleröd, 2011). The concepts of past and future in the construction of lifelong learning can link and harmonize the interests of the individual, society, and the future, which can be emphasized in schools and education according to Petersson, Olsson, and Popkewitz (2007).

Popular education's role in local development in rural areas has been linked to village movement; it is dominated by bottom- up approaches and strongly linked to voluntary work carried out by the local inhabitants themselves in Sweden, which are presented by Eriksson and Forsberg (2010) and discussed in relation to theories of social development and common identity.

The driving forces associated with young people's experiences of the home municipality Söderhamn and migration from smaller towns have been researched by Eriksson, $(2006, b)$ under the heading "Winning and Disappear." Young people are forced to relate consciously to norms of "youth" and "normality". The interacting factors demonstrate large differences in adolescents' actual and perceived influence and participation. Young people who wanted to stay in the region did not feel wanted by the local rulers, and this made the paradox concerning which young people and "who count" clear. Young people's views on participation are not matched by the adults' perception of how young people should take part in political life (Svensson, 2006, a).In summary, these five sub- themes, women's situation, mental images, historical awareness, handling popular education using a top-down approach, and changing the view adolescents' life path choices, could be important for school development in rural areas. 


\section{Concluding Reflections}

\subsection{Results}

In summary, this integrative literature review revealed a sprawling result: there has been too little debate, and the sources were descriptive studies, for example, historical overviews or descriptive evaluations. In addition, one-third of the sources were official reports. The discussions, debates, and investments pertaining to universities and education programs' role in the Swedish rural areas began in the mid-1980s. Even then, the role of universities for rural and Sweden's prosperity was discussed in the light of increased global competition. The most important factor for the development of the municipalities and the regions seemed to be education and a connection to research and innovation regarding the development of rural areas (e.g.,Crescenzi, 2005; From \&Olofsson, 2013; Hernandez \& Goodson, 2010; Veuglers $\&$ Ziljstra, 2010). At the end of 1990, higher education expanded with great expectations about growth in the regions. The state invested several hundred million in a few projects in 1995-2005 on education for adults and collaboration between municipalities and higher education.

Results obtained from this investment are cooperative structures, learning centers in the municipalities, developmental entrepreneurship projects, and workforce supply. However, these results show that premises from the government should have been clearer, project proposals must be based on real regional needs; fixed resources and a long-term strategy would have been desirable. These large government economic initiatives strengthened the likely possibilities for adults to study and stay in rural areas, such as strengthening learning centers in many rural municipalities. The focus was more of a practical nature namely trying to create more jobs and there were no clear ideological rewrites or a long-term strategy. None of these efforts in regional educational development include education of youths.

A region that, in the 1990s, had already distinguished itself from the rest of Sweden was Västra Götaland (Weibull \& Nilsson, 2010; Nilsson, 2000). It formed the early region in this area, interacted widely with the college, and created good relations with the public. The idea of a coherent and uniform education permeated the region where citizens, educators, and politicians engaged across school boundaries and ideological barriers. The road to knowledge-intensive societies through the university was clear. A dozen regional development projects were evaluated during the years 1973-2013. These are mostly good examples of how people in towns, districts, or regions managed different projects, from new regional collaboration to the creation of innovative production, to higher vocational education in rural areas, to women's entrepreneurship. They can serve as good examples, but the scientific follow-ups and evaluations would have benefitted from more scientific designs. They are mostly descriptive reports without a methodological approach. Since many projects appear to have been successful, it would be beneficial, from a societal perspective, to extract a lot more knowledge with greater awareness of monitoring and evaluation.

Clearly, the large expansive regions have developed (i.e., have been promoted) and expanded, while rural areas have not had this development (Bergström- Levander, 2003; Gullstrand \& Hammarlund, 2007). Rather, these areas have failed to flourish and development is stagnant. 
One can also ask where regional political strategies are with a holistic approach. The government invested a lot of money during 1990-2005, but what have the rural regions gotten out of this? Did it have the desired effect? Paradoxically, the knowledge of prosperity has increasing regional disparities, which Sörlin warned of in 2000. The research clearly shows that education and opportunity/proximity to the university are important for regional development (Sörlin, 2000), but something more is needed. The question, though, is what?

Perhaps we see in this project actors or informal institutions of civil society that see themselves as emerging institutions, when the formal institutions do not seem to function properly when it comes to regional development and education. With no formal education or constitutional factors may guide development in the countryside in a positive regard, impulses from, for example, associations, social groups and businesses to bring about changes

This overview shows the absence of previous relevant research for our project. There is no research and there are no debates ranging from preschool through the whole school system. Good education systems, ranging from preschool to universities, are vital for development. This mutual relationship is described and emphasizes that initiatives in the classroom or department are influenced by the surrounding context of the school, the district, and the nation (Hernandez \& Goodson, 2010; Veugelers \& Ziljsra, 2010). Studies about the school improvement and the impacts on students and regional development are also missing. Young people's and women's voices are also absent. One explanation may be that existing institutions do not function properly for regional development (cf, Douglas, 1990). Therefore, representatives of civil society made themselves a part of institution-building and $o$ in to affect school and training for regional development.

\subsection{Pedagogical Implications}

There are many pedagogical implications to address. First, it is important to evaluate the attitudes generally speaking in schools and society in rural areas concerning regional educational development. What is better and worse for young people's development and future in rural areas? The winning-and-disappearing mentality could be problematized. Are young men/women winners if they move to a big city and study? Or, can they be winners if they stay in the countryside working and studying? There is need for a review of life values in schools in rural areas. What implicit or explicit values are passed on about the future in the rural area? How can teachers influence future beliefs about the rural areas? Furthermore, it is equally relevant to consider the potential impact of regional educational improvements throughout the school system.

Another issue is to listen to youth and women's voices and discuss with them what is necessary for them to stay on and enjoy the countryside. What are their visions? What is needed for them to stay?

An implication for the government is to value a unified regional political grip on the whole educational system and have a long-term strategy. What is the intention behind regional educational development and different projects? This study is highly relevant for Nordic 
educational research because of problems with regional equality, expertise relocating, and repercussions for the entire education system.

\section{References}

Ahuvia, A. (2008). Traditional, interpretative and reception based content analyses: Improving the ability of content analysis to address issues of pragmatic and theoretical concern. In R. Franzosi (ed.), Content Analysis, Volume 1 (pp. 183-202). London: SAGE. http://dx.doi.org/10.1023/A:1011087813505

Ambos, B., \&Schlegelmilch, B. (2010).The new role of regional management. Vienna: Palgrave Macmillan.

Asplund, E., Lagerkvist, A., Heydebreck, P., Dahlén, L., \& Norberg, A. (2009). Framsyn för Norrbotten och Västerbotten: en idéskrift om utvecklingsinsatser idag och imorgon.[Foresight for Norrbotten and Västerbotten: an idea publication written about development today and tomorrow]. Luleå: Luleå Tekniska Universitet.

Augustinsson, S. \& Nilsson, A. (2005). Regional hållbar utveckling: fallet Osby Nova. [Regional sustainable development: the caseof Osby Nova.] In J. Lindelöf (ed.), Lärande hela livet: en antologi om lärandets betydelse för utveckling $i$ arbetsliv och samhälle (pp. 109-121). Lund: Studentlitteratur.

Bergström-Levander, I. (2003). Befolkning och utbildning: ökade regionala skillnader. [Population and education: increasing regional disparities.] Välfärd, 4, 12-13.

Braun, V., \& Clarke, V. (2006). Using thematic analysis in psychology. Qualitative Research in Psychology, 5, 77-101. http://dx.doi.org/10.1191/1478088706qp063oa

Cooper, H. (1998). Synthesizing research: A guide for literature reviews. Thousand Oaks, California: SAGE.

Crescneszi, R. (2005). Innovation and regional growth in enlarged Europe: The role of local innovative capabilities, peripherality, and education. Growth and Change, 36(4), 471- 507. http://dx.doi.org/10.1191/1478088706qp063oa

Dahlström, M. (1996). Young women in a male periphery-Experiences from the Scandinavian north. Journal of Rural Studies, 12(3), 259-271. http://dx.doi.org/10.1016/0743-0167(96)00018-6

Dimenäs, J., Kolbeck, K., Wede, C., \& Norlund, A. (2013). "En trygg och framgångsrik skola"-pedagogiska övertygelser i fyra landsortsskolor. [“A safe and successful school"- educational beliefs in four rural schools.] Utbildning \& Demokrati, 2, 81-104.

Ericsson, A. L. (1987). Kvinnors ställning på arbetsmarknaden och i utbildningssystemet: en analys baserad på rapporter från länsstyrelserna.[The position of women in the labor market and in education: an analysis based on reports from the County Board.] Stockholm: ERU.

Eriksson, L., \& Forsberg, A. (2010). The part played by popular education in local development processes in suburban and rural areas of Sweden. International Journal of 
Lifelong Education, 29(3), 323-341. http://dx.doi.org/10.1080/02601371003700626

Evans, D. (2008). Integrative review of qualitative and quantitative research. In Webb, C \& Roe, B. (Eds). Reviewing Research Evidence for Nursing Practice. Blackwell Publishing, Oxford, pp. 137 - 147.

Florida, R (2002). The rise of the creative class and how it's transforming work, leisure, community and everyday life. New York: Basic Books.

Florida, R., Mellander, C. \& Stolarick, K. (2010). Talent, technology and tolerance in Canadian regional development. The Canadian Geographer, 54(3), 277-304. http://dx.doi.org/10.1111/j.1541-0064.2009.00293.x

FoU, Aktuellt. (2005). Starka krafter i mellersta Sverige.[Strong forces in central Sweden]. Aktuell Forskning \& Utveckling, 2, 80-81.

Franzosi, R. (2008). Content analysis: Objective, systematic, and quantitative description of content. In R. Franzosi (Ed.), Content analysis, Volume 1 (pp. xxi-xli). London: SAGE.

Fregidou-Malama, M., \& Jakobson, S. (2008). Etablering av regional yrkeshögskoleutbildning i Hofors och Sandviken. [Establishment of a regional polytechnic in Hofors and Sandviken]. Working paper, No 40. Gävle: Högskolan i Gävle.

From, J. \& Olofsson, A. (2014). Kunskapsekonomi och regional utveckling. [Knowledge Economy and Regional Development]. In Y. Fiedrichs, M. Gawell\& J. Wincent (Eds.), Samhällsentreprenörskap för lokalutveckling (pp. 17-42). Sundsvall: Mittuniversitetet.

George, A. L. (2008). Quantitative and qualitative approaches to content analysis. In R. Franzosi (Ed.), Content Analysis, Volume1 (pp. 178 - 192). London: SAGE.

Gullstrand, C., \& Hammarlund, J. (2007). Högskolesatsning i glesbygd försvagar Sveriges tillväxt. [Higher Investment in rural weaken Sweden's growth.] DN, 27(4), 6.

Halleröd, B. (2011). What do children know about their futures: Do children's expectations predict outcomes in middle age? Social Forces, 90(1), 65-84. http://dx.doi.org/10.1093/sf/90.1.65

Hammar, S., \& Svensson, L. (2005). Vem är det som ska lyssna då? Ungdomar-social kapital-regional utveckling. [Who is going to listen then? Young people-social capital—Regional Development]. Söderhamn: FoU-Centrum Söderhamn.

Hård, U. (2007). Att släppas in i "verkligheten”- erfarenheter från en forskningsresa. [To be released into the "real world"-experiences from a research trip.] In FoU-centrum i Söderhamn (Ed.), Arbetsrapport från FoU-Centrum Söderhamn. Söderhamn: Publisher.

Hernandez, F. G. (2010). Social geographies of educational changes: Drawing a map for curious and dissatisfied travellers. In F. G. Hernandez (Ed.), Social geographies of educational changes (pp. xi-xxi). Dordrecht: Kluwer Academic Publisher.

Holmgren, A. (2007). Utbildning för arbetslivet: en reportagebok om hur lärcentra bidrar till 
lokal och regional utveckling. [Education for the working place: a documentary about how learning centers contribute to local and regional development]. Stockholm: TCO.

Hudson, C. (2001). Regionala partnerskap—ett hot mot eller ett förverkligande av demokrati? [Regional partnerships — a threat or a realization of democracy?] Working paper 36:2001. Umeå: CERUM, Umeå Universitet.

Lorendahl, B., \& Persson, L. O. (1992). Utbildning för utkanter: rapport från ett seminarium i Östersund i juni 1991.[Education for outskirts: report of a seminar held in Östersund in June 1991]. Östersund: Högskolan i Östersund i samarbete med Expertgruppen för forskning om regional utveckling ERU.

Lundgren, M. (2007). Projektet: W7 DALARNA-Ett regionalt resurscentrum för kvinnligt entreprenörskap, jämställdhet och integration.[Project: W7 Dalarna—a regional resource center for female entrepreneurship, equality and integration]. Rapport 2007:13. Falun: Högskolan Dalarna.

Nilsson, L. (2000). Den nya regionen: SOM-undersökningen Västsverige 1999. [The new region: SOM survey western Sweden in 1999.] Göteborg: SOM-institutet, Göteborgs universitet.

North, D. (1990). Institutions, institutional changes and economics. Cambridge: Cambridge University Press. http://dx.doi.org/10.1017/CBO9780511808678

Olofsson, A. (2006). Utbildning för förändrat samhälle. [Education for changed society]. Sundsvalls tidning 9 (11), 30.

Olsson, B., \& Wiberg, U. (2003). Universitetet och den regionala utmaningen. [The university and the regional challenge.]. Stockholm: Institutet för studier av utbildning och forskning.

Östlund, H.-E. (1986). Spjutspets eller släpvagn? Utbildningens roll i ekonomisk och regional utveckling. [Cutting edge or trailer? The role of education in economic and regional development]. Stockholm: Liber Utbildningsförlag.

Persson, L. S.-M. (2003). Rural communities facing challenges and conflicts. In L. S.-M. Persson (Ed.), Local Responses to Global Changes (pp. 1-9). Stockholm: National Institute for Working Life. http://dx.doi.org/10.1080/01596300601073598

Petersson, K., Olsson, U., \& Popkewitz, T. (2007). Nostalgia, the future, and the past as pedagogical technologies. Discourse: Studies in the Cultural Politics of Education, 28(1), 49-67. http://dx.doi.org/10.1080/01596300601073598

Polit, D.\& Beck, C. (2008). Nursing research: Generating and assessing. Philadelphia: Lippincott, Williams \& Wilkins.

Qvist, M. (2011). Utveckling genom regional samverkan?: Insatser för arbete och entreprenörskap inom introduktionen för nyanlända invandrare i Sörmland. [Development through regional collaboration?: Actions for work and entrepreneurship in the introduction of 
newly arrived immigrants in Södermanland]. Norrköping: REMESO; Institute for Research on Migration, Ethnicality and Society.

Rylander, D., Ebbesson, I., Törn, E., \& Abbasian, S. (2010). Gnosjöandan i ny riktning: Regional samverkan inom design, upplevelser, kulturarv. [Gnosjöandan in new direction: Regional collaboration in design, experiences, cultural heritage]. In B. Johansson \& D. Rylander, (Ed.), Entreprenörskap i regioners tjänst: Ingångar till nya näringar genom design, upplevelser, kulturarv (pp. 207-256). Stockholm:

SBU. (2013). Utvärdering av metoder i hälso- och sjukvården: En handbok. [Evaluation of methods in healthcare: A handbook]. Version 2013-05-16. Stockholm: Statens beredning för medicinsk utvärdering (SBU).

Skolverket. (2014). SALSA/ SIRIS. $\quad$ Retrieved from http://www.skolverket.se/statistik-och-utvardering/statistik-i-databaser. 2014-02-02

Sörlin, S. (2000). Kunskap för välstånd: ökade regionala skillnader. [Knowledge of prosperity: increasing regional disparities.] Stockholm: SNS Studieförb. Näringsliv och samhälle.

Statistiska Centralbyrån (2014). Utflyttande högskoleutbildade från Jämtlands och Västernorrlands län. [Out-migration of college-educated in Jämtlands and Västernorrlands counties compared to the whole of Sweden]. Retrieved from http://www.scb.se/sv_/Hitta-statistik/, 2014-02-02

Svensson, L. (2006). Här får du inte vara med om du inte flyttar härifrån: Om ungdom och regional utveckling. [Here you will not be counted on if you are not moving from here: Youth and regional development]. Locus, 2006(3), pp.21-34.

Svensson, L. (2006). Vinna och försvinna? Drivkrafter bakom ungdomars utflyttning från mindre orter. [Winning and disappear? Levers of youth out-migration from small villages.] Linköping: Linköping Studies in Education and Psychology.

UHÄ-rapport. (1992a). Utbildning som instrument för regional utveckling.Rapport U4, En enkätundersökningi 40 kommuner. [Education as an instrument of regional development. Report U4, A survey in 40 municipalities.] Stockholm: Universitets- och högskoleämbetet UHÄ.

UHÄ-rapport. (1992b). Utbildning som instrument för regional utveckling. Rapport U5, En utvärderingsstudie i sex kommuner. [Education as an instrument of regional development. Report U5, A evaluation study in 40 municipalities.] Stockholm: Universitets- och högskoleämbetet UHÄ.

UHÄ-rapport. (1992c). Utbildning som instrument för regional utveckling. Slutrapport. En utvärderingsstudie i sex kommuner. [Education as an instrument of regional development. Final Report.] UHÄ-rapport, 1992:17. Stockholm: Universitets- och högskoleämbetet UHÄ.

Unge, S., \& Samverkansdelegationen. (2005). Ett samlat grepp: samverkan om utbildning för utveckling och tillväxt: exempelsamling. [A comprehensive approach: collaboration on 
education for development and growth: examples collection]. Stockholm: Delegationen för regional samverkan om högre utbildning, Regeringskansliet.

Unge, S., \& Samverkansdelegationen. (2005). Ett samlat grepp: samverkan om utbildning för utveckling och tillväxt: slutrapport. [A comprehensive approach: collaboration on education for development and growth: final report]. Stockholm: Delegationen för regional samverkan om högre utbildning, Regeringskansliet

Veugelers, W., \&Zijlstra, H. (2010). Networks of schools and constructing citizenship in secondary education. In F. Hernandez \& I. Goodson (Eds.), Social geographies of educational changes (pp. 65-78). Dordrecht: Kluwer Academic Publishers.

Weibull, L., \& Nilsson, L. (2010). Regional utveckling i Västra Götaland-högre utbildning och Forskning. [Regional development in Västra Götaland-Higher Education and Research]. In L. N. (red.), En region blir till. Västra Götalandsregionen 199-2008. (pp. 193 -223). Göteborg: SOM-institutet. Göteborgs Universitet.

Westlund, H. (2004). Regionala effekter av högre utbildning, högskolor och universitet: en kunskapsöversikt.[Regional effects of higher education, colleges and universities: a systematic review]. Östersund: Institutet för tillväxtpolitiska studier ; A2004:002.

Westlund, H., Deiaco, E., \& Johansson, M. (2005). Utvärdering av delegationen för regional samverkan om högre utbildning: A2005:014. [Evaluation of the delegation for regional collaboration on higher education]. Östersund: Institutet för tillväxtpolitiska studier ITPS.

Whittemore, R., \& Knafl, K. (2005). The integrative review: updated methodology. Journal of Advanced Nursing, 52, 246-253. http://dx.doi.org/10.1111/j.1365-2648.2005.03621.x

\section{Appendix}

Appendix 1.

Table 1. Distribution of themes

\begin{tabular}{lll}
\hline Themes & $\begin{array}{l}\text { \# of Articles } \\
\mathrm{N}=38\end{array}$ & $\begin{array}{l}\% \text { of } \\
\text { articles }\end{array}$ \\
\hline $\begin{array}{l}\text { HE \& Research } \\
\text { Regional educational initiatives }\end{array}$ & 4 & $10,5 \%$ \\
$\begin{array}{l}\text { HE \& research+ } \\
\text { Regional projects }\end{array}$ & 3 & $7,9 \%$ \\
HE \& Research + Regional educational & 2 & $5,2 \%$ \\
initiatives & 2 & \\
$\begin{array}{l}\text { Regional projects } \\
\text { Women }\end{array}$ & & $5,2 \%$ \\
Women, Regional & projects+ educational & \\
initiatives & 11 & $28,9 \%$ \\
Mental images & 4 & $10,5 \%$ \\
Debate & & $2,6 \%$ \\
\hline
\end{tabular}


Table 2. Distribution of sources reviewed by year

\begin{tabular}{lll}
\hline Years & $\begin{array}{l}\text { \# of Articles } \\
\mathrm{N}=38\end{array}$ & $\begin{array}{l}\% \text { of } \\
\text { articles }\end{array}$ \\
\hline $1983-1989$ & 2 & $5,3 \%$ \\
$1990-1995$ & 5 & $13,1 \%$ \\
$1996-2000$ & 2 & $5,3 \%$ \\
$2001-2005$ & 13 & $34,2 \%$ \\
$2006-2010$ & 13 & $34,2 \%$ \\
$2011-$ & 3 & $7,9 \%$ \\
\hline
\end{tabular}

Table 3. Distribution of sources reviewed by year

\begin{tabular}{llc}
\hline Distribution of sources & $\begin{array}{l}\# \text { of Articles } \\
\mathrm{N}=38\end{array}$ & $\begin{array}{l}\% \text { of } \\
\text { articles }\end{array}$ \\
\hline Articles & 10 & $26,3 \%$ \\
Dissertation & 1 & $2,6 \%$ \\
Books & 8 & $21,0 \%$ \\
Book chapters & 3 & $7,9 \%$ \\
Debate/articles & 3 & $7,9 \%$ \\
Reports & 13 & $34,2 \%$ \\
\hline
\end{tabular}

Table 4. Distribution of methodological approach

\begin{tabular}{lll}
\hline Methodological approach & $\begin{array}{l}\text { \# of Articles } \\
\mathrm{N}=38\end{array}$ & $\begin{array}{l}\% \text { of } \\
\text { articles }\end{array}$ \\
\hline Qualitative & 36 & $94,7 \%$ \\
Quantitative & 2 & $5,3 \%$ \\
\hline
\end{tabular}

Table 5. Distribution of Relevance

\begin{tabular}{lll}
\hline Relevance & \# of Articles & \% of articles \\
& $\mathrm{N}=38$ & \\
\hline High & 13 & $34,2 \%$ \\
Medium & 16 & $42,1 \%$ \\
Low & 9 & $23,7 \%$ \\
\hline
\end{tabular}

Tabel 3. Languages

\begin{tabular}{lcc}
\hline Language & $\begin{array}{c}\text { \# of Articles } \\
\mathrm{N}=38\end{array}$ & \% of articles \\
& 3 & $7,9 \%$ \\
English & 35 & $92,1 \%$ \\
\hline
\end{tabular}


Appendix 2. Article matrix

\begin{tabular}{|c|c|c|c|c|c|c|c|c|}
\hline & Author & Year & Country & $\begin{array}{l}\text { Methodolo- } \\
\text { gical } \\
\text { Approach }\end{array}$ & $\begin{array}{l}\text { Data } \\
\text { collecting }\end{array}$ & $\begin{array}{l}\text { Analysis } \\
\text { Level }\end{array}$ & $\begin{array}{l}\text { Rele- } \\
\text { vance }\end{array}$ & Theme \\
\hline 1. & Weibull, L. \& Nilsson, L. & 2010 & Sweden & $\begin{array}{l}\text { Qualitative } \\
\text { study, } \\
\text { descriptive }\end{array}$ & $\begin{array}{l}\text { Literature } \\
\text { study }\end{array}$ & $\begin{array}{l}\text { Content } \\
\text { Analysis }\end{array}$ & High & $\begin{array}{l}\mathrm{HE} \& \\
\text { research }\end{array}$ \\
\hline 2 & UHÄ-rapport & 1992 & Sweden & $\begin{array}{l}\text { Quantitative } \\
\text { study, } \\
\text { descriptive }\end{array}$ & Survey study & $\begin{array}{l}\text { Content } \\
\text { Analysis }\end{array}$ & Medium & $\begin{array}{l}\text { Regional } \\
\text { projects }\end{array}$ \\
\hline 3 & UHÄ-rapport & 1992 & Sweden & $\begin{array}{l}\text { Qualitative } \\
\text { study, } \\
\text { descriptive }\end{array}$ & $\begin{array}{l}\text { Interviews, } \\
\text { document } \\
\text { studies, } \\
\text { strategy } \\
\text { studies }\end{array}$ & $\begin{array}{l}\text { Content } \\
\text { Analysis }\end{array}$ & Medium & $\begin{array}{l}\text { Regional } \\
\text { projects }\end{array}$ \\
\hline 4 & UHÄ-rapport & 1992 & Sweden & $\begin{array}{l}\text { Qualitative } \\
\text { study, } \\
\text { descriptive }\end{array}$ & $\begin{array}{l}\text { Literature, } \\
\text { surveys, } \\
\text { documents, } \\
\text { interviews }\end{array}$ & $\begin{array}{l}\text { Content } \\
\text { Analysis }\end{array}$ & Medium & $\begin{array}{l}\text { Regional } \\
\text { projects }\end{array}$ \\
\hline 5 & Sörlin, S & 2000 & Sweden & $\begin{array}{l}\text { Qualitative } \\
\text { study, } \\
\text { descriptive }\end{array}$ & $\begin{array}{l}\text { Literature } \\
\text { study }\end{array}$ & $\begin{array}{l}\text { Content } \\
\text { Analysis }\end{array}$ & Medium & $\begin{array}{l}\mathrm{HE} \& \\
\text { research }\end{array}$ \\
\hline 6 & Bergström-Levander, I. & 2003 & Sweden & $\begin{array}{l}\text { Qualitative } \\
\text { study, } \\
\text { descriptive }\end{array}$ & $\begin{array}{l}\text { Literature } \\
\text { study }\end{array}$ & $\begin{array}{l}\text { Content } \\
\text { Analysis }\end{array}$ & High & Debate \\
\hline 7 & Nilsson, L. & 2000 & Sweden & $\begin{array}{l}\text { Qualitative } \\
\text { study, } \\
\text { descriptive }\end{array}$ & $\begin{array}{l}\text { Qualitative } \\
\text { study, } \\
\text { descriptive }\end{array}$ & $\begin{array}{l}\text { Content } \\
\text { Analysis }\end{array}$ & High & $\begin{array}{l}\text { HE \& } \\
\text { research+ } \\
\text { Regional } \\
\text { projects }\end{array}$ \\
\hline 8 & $\begin{array}{l}\text { Gullstrand, J. \& } \\
\text { Hammarlund, C. }\end{array}$ & 2007 & Sweden & $\begin{array}{l}\text { Qualitative } \\
\text { study, } \\
\text { descriptive }\end{array}$ & $\begin{array}{l}\text { Qualitative } \\
\text { study, } \\
\text { descriptive }\end{array}$ & $\begin{array}{l}\text { Content } \\
\text { Analysis }\end{array}$ & High & Debate \\
\hline 9 & Holmgren, A & 2007 & Sweden & $\begin{array}{l}\text { Qualitative } \\
\text { study, } \\
\text { descriptive }\end{array}$ & Case studies & $\begin{array}{l}\text { Content } \\
\text { Analysis }\end{array}$ & Medium & $\begin{array}{l}\text { Regional } \\
\text { initiatives }\end{array}$ \\
\hline 10 & $\begin{array}{l}\text { Augustsson, } \quad \text { S. } \quad \& \\
\text { Nilsson, A. }\end{array}$ & 2005 & Sweden & $\begin{array}{l}\text { Qualitative } \\
\text { study, } \\
\text { descriptive }\end{array}$ & Case studies & $\begin{array}{l}\text { Content } \\
\text { Analysis }\end{array}$ & Low & $\begin{array}{l}\text { Regional } \\
\text { projects }\end{array}$ \\
\hline 11 & Olofsson, A & 2006 & Sweden & $\begin{array}{l}\text { Qualitative } \\
\text { study, } \\
\text { descriptive }\end{array}$ & $\begin{array}{l}\text { Literature } \\
\text { study }\end{array}$ & $\begin{array}{l}\text { Content } \\
\text { Analysis }\end{array}$ & High & Debate \\
\hline 12 & Westlund, H, Deiaco, E. & 2005 & Sweden & Qualitative & Document & Content & High & Regional \\
\hline
\end{tabular}




\begin{tabular}{|c|c|c|c|c|c|c|c|c|}
\hline & \& Johansson, M. & & & $\begin{array}{l}\text { study, } \\
\text { descriptive }\end{array}$ & $\begin{array}{l}\text { studies, case } \\
\text { studies }\end{array}$ & Analysis & & projects \\
\hline 13 & $\begin{array}{l}\text { Rylander, D., Ebbesson, } \\
\text { I., Törn, E. \& Abbasioan, } \\
\text { S. }\end{array}$ & 2010 & Sweden & $\begin{array}{l}\text { Qualitative } \\
\text { study, } \\
\text { Descriptive }\end{array}$ & $\begin{array}{l}\text { Literature } \\
\text { study }\end{array}$ & $\begin{array}{l}\text { Content } \\
\text { Analysis }\end{array}$ & Low & $\begin{array}{l}\text { Regional } \\
\text { initiatives }\end{array}$ \\
\hline 14 & Samverkandelegationen & 2005 & Sweden & $\begin{array}{l}\text { Qualitative } \\
\text { study, } \\
\text { descriptive }\end{array}$ & $\begin{array}{l}\text { Document } \\
\text { studies, case } \\
\text { studies }\end{array}$ & $\begin{array}{l}\text { Content } \\
\text { Analysis }\end{array}$ & Medium & $\begin{array}{l}\text { Regional } \\
\text { projects }\end{array}$ \\
\hline 15 & $\begin{array}{l}\text { Lorendahl, B.\& Persson, } \\
\text { L.O. }\end{array}$ & 1992 & Sweden & $\begin{array}{l}\text { Qualitative } \\
\text { study, } \\
\text { descriptive }\end{array}$ & $\begin{array}{l}\text { Literature } \\
\text { study, } \\
\text { document } \\
\text { studies }\end{array}$ & $\begin{array}{l}\text { Content } \\
\text { Analysis }\end{array}$ & Medium & $\begin{array}{l}\text { Regional } \\
\text { projects }+ \\
\text { Regional } \\
\text { initiatives }\end{array}$ \\
\hline 16 & $\begin{array}{l}\text { Unge, } \quad \text { S. } \quad \& \\
\text { Samverkansdelegationen }\end{array}$ & 2005 & Sweden & $\begin{array}{l}\text { Qualitative } \\
\text { study, } \\
\text { descriptive }\end{array}$ & $\begin{array}{l}\text { Literature } \\
\text { study, } \\
\text { document } \\
\text { studies, }\end{array}$ & $\begin{array}{l}\text { Content } \\
\text { Analysis }\end{array}$ & Low & $\begin{array}{l}\text { Regional } \\
\text { projects }\end{array}$ \\
\hline 17 & $\begin{array}{l}\text { Unge, } \quad \text { S. \& \& } \\
\text { Samverkansdelgationen }\end{array}$ & 2005 & Sweden & Descriptions & $\begin{array}{l}\text { Descriptions } \\
\text { of cases }\end{array}$ & Descriptions & Low & $\begin{array}{l}\text { Regional } \\
\text { projects }\end{array}$ \\
\hline 18 & Qvist, M. & 2011 & Sweden & $\begin{array}{l}\text { Qualitative } \\
\text { study, } \\
\text { descriptive }\end{array}$ & $\begin{array}{l}\text { Interviews, } \\
\text { documents } \\
\text { observations }\end{array}$ & $\begin{array}{l}\text { Content } \\
\text { Analysis }\end{array}$ & Low & $\begin{array}{l}\text { Regional } \\
\text { projects }+ \\
\text { Regional } \\
\text { initiatives }\end{array}$ \\
\hline 19 & $\begin{array}{l}\text { Fregidou -Malarna, M \& } \\
\text { Jakobsson, S. }\end{array}$ & 2008 & Sweden & $\begin{array}{l}\text { Qualitative } \\
\text { study, } \\
\text { descriptive }\end{array}$ & $\begin{array}{l}\text { Document } \\
\text { studies, } \\
\text { interviews, } \\
\text { focus group } \\
\text { interviews }\end{array}$ & $\begin{array}{l}\text { Content } \\
\text { Analysis }\end{array}$ & Low & $\begin{array}{l}\text { Regional } \\
\text { projects }\end{array}$ \\
\hline 20 & $\begin{array}{l}\text { FoU-centrum } \\
\text { Söderhamn }\end{array}$ & 2005 & Sweden & $\begin{array}{l}\text { Qualitative } \\
\text { study, } \\
\text { descriptive }\end{array}$ & $\begin{array}{l}\text { Research } \\
\text { review, } \\
\text { Literature } \\
\text { study, }\end{array}$ & $\begin{array}{l}\text { Content } \\
\text { Analysis }\end{array}$ & High & $\begin{array}{l}\mathrm{HE} \& \\
\text { research, } \\
\text { Regional } \\
\text { projects }\end{array}$ \\
\hline 21 & Östlund, H.-E. & 1986 & Sweden & $\begin{array}{l}\text { Qualitative } \\
\text { study, } \\
\text { descriptive }\end{array}$ & $\begin{array}{l}\text { Qualitative } \\
\text { study, } \\
\text { descriptive }\end{array}$ & $\begin{array}{l}\text { Content } \\
\text { Analysis }\end{array}$ & Medium & $\begin{array}{l}\text { Regional } \\
\text { initiatives }\end{array}$ \\
\hline 22 & Westlund, H. & 2004 & Sweden & $\begin{array}{l}\text { Qualitative } \\
\text { study, } \\
\text { descriptive }\end{array}$ & $\begin{array}{l}\text { Qualitative } \\
\text { study, } \\
\text { descriptive }\end{array}$ & $\begin{array}{l}\text { Content } \\
\text { Analysis }\end{array}$ & Medium & $\begin{array}{l}\mathrm{HE} \quad \& \\
\text { research }\end{array}$ \\
\hline 23 & Eriksson, A-L. & 1987 & Sweden & $\begin{array}{l}\text { Qualitative } \\
\text { study, } \\
\text { descriptive }\end{array}$ & $\begin{array}{l}\text { Literature } \\
\text { study, } \\
\text { Document } \\
\text { studies, }\end{array}$ & $\begin{array}{l}\text { Content } \\
\text { Analysis }\end{array}$ & Medium & Women \\
\hline 24 & Olsson, B. \& Wiberg, U. & 2003 & Sweden & $\begin{array}{l}\text { Qualitative } \\
\text { study, }\end{array}$ & $\begin{array}{l}\text { Literature } \\
\text { study, }\end{array}$ & $\begin{array}{l}\text { Content } \\
\text { Analysis }\end{array}$ & Low & $\begin{array}{l}\mathrm{HE} \quad \& \\
\text { research }\end{array}$ \\
\hline
\end{tabular}




\begin{tabular}{|c|c|c|c|c|c|c|c|c|}
\hline & & & & descriptive & $\begin{array}{l}\text { Document } \\
\text { studies, }\end{array}$ & & & \\
\hline 25 & Hudson, C. & 2001 & Sweden & $\begin{array}{l}\text { Qualitative } \\
\text { study, } \\
\text { descriptive }\end{array}$ & $\begin{array}{l}\text { Literature } \\
\text { study, } \\
\text { Document } \\
\text { studies, } \\
\text { case studies }\end{array}$ & $\begin{array}{l}\text { Content } \\
\text { Analysis }\end{array}$ & High & Debate \\
\hline 26 & Lundgren, $\mathrm{M}$. & 2007 & Sweden & $\begin{array}{l}\text { Qualitative } \\
\text { study, } \\
\text { descriptive }\end{array}$ & $\begin{array}{l}\text { Documents, } \\
\text { observations, } \\
\text { survey }\end{array}$ & $\begin{array}{l}\text { Content } \\
\text { Analysis }\end{array}$ & Medium & $\begin{array}{l}\text { Regional } \\
\text { projects }\end{array}$ \\
\hline 27 & $\begin{array}{l}\text { Asplund, E. , Lagerqvist, } \\
\text { A, Heydebreck, P. } \\
\text { Dahlén, L. \& Norberg, } \\
\text { A. }\end{array}$ & 2009 & Sweden & $\begin{array}{l}\text { Qualitative } \\
\text { study, } \\
\text { descriptive }\end{array}$ & $\begin{array}{l}\text { Literature } \\
\text { study, } \\
\text { document } \\
\text { studies, } \\
\text { interviews, }\end{array}$ & $\begin{array}{l}\text { Content } \\
\text { Analysis }\end{array}$ & Medium & $\begin{array}{l}\text { Regional } \\
\text { projects }\end{array}$ \\
\hline 28 & Halleröd, B. & 2011 & Sweden & $\begin{array}{l}\text { Quantitative } \\
\text { study, } \\
\text { descriptive }\end{array}$ & Surveys & $\begin{array}{l}\text { Content } \\
\text { Analysis }\end{array}$ & High & Women \\
\hline 29 & $\begin{array}{l}\text { Eriksson, L. \& Forsberg, } \\
\text { A, }\end{array}$ & 2010 & Sweden & $\begin{array}{l}\text { Multi } \\
\text { Methods }\end{array}$ & $\begin{array}{l}\text { Literature } \\
\text { study, } \\
\text { document } \\
\text { studies, } \\
\text { interview, } \\
\text { surveys, }\end{array}$ & $\begin{array}{l}\text { Content } \\
\text { Analysis }\end{array}$ & High & $\begin{array}{l}\text { Mental } \\
\text { images }\end{array}$ \\
\hline 30 & $\begin{array}{l}\text { Aktuell forskning \& } \\
\text { Utveckling }\end{array}$ & 2005 & Sweden & Descriptive & $\begin{array}{l}\text { Literature } \\
\text { study, } \\
\text { Document } \\
\text { studies, }\end{array}$ & $\begin{array}{l}\text { Content } \\
\text { Analysis }\end{array}$ & Medium & Debate \\
\hline 31 & Svensson, L. & 2006 & Sweden & $\begin{array}{l}\text { Interactive } \\
\text { research } \\
\text { approach }\end{array}$ & $\begin{array}{l}\text { Surveys, } \\
\text { interviews, , } \\
\text { focus group } \\
\text { interviews }\end{array}$ & $\begin{array}{l}\text { Content } \\
\text { Analysis }\end{array}$ & High & $\begin{array}{l}\text { Mental } \\
\text { images }\end{array}$ \\
\hline 32 & Eriksson, L. & 2006 & Sweden & $\begin{array}{l}\text { Interactive } \\
\text { research } \\
\text { approach }\end{array}$ & $\begin{array}{l}\text { Focus group } \\
\text { interviews }\end{array}$ & $\begin{array}{l}\text { Content } \\
\text { Analysis }\end{array}$ & High & $\begin{array}{l}\text { Mental } \\
\text { images }\end{array}$ \\
\hline 33 & $\begin{array}{l}\text { Hammar, S \& Svensson, } \\
\text { L }\end{array}$ & 2005 & Sweden & $\begin{array}{l}\text { Interactive } \\
\text { research } \\
\text { approach }\end{array}$ & $\begin{array}{l}\text { Surveys } \\
\text { focus group } \\
\text { interviews }\end{array}$ & $\begin{array}{l}\text { Content } \\
\text { Analysis }\end{array}$ & Medium & Women \\
\hline 34 & Hård Ursula & 2007 & Sweden & $\begin{array}{l}\text { Qualitative } \\
\text { study, } \\
\text { descriptive }\end{array}$ & Surveys & $\begin{array}{l}\text { Qualitative } \\
\text { study, } \\
\text { descriptive }\end{array}$ & Low & Women \\
\hline
\end{tabular}




\begin{tabular}{|c|c|c|c|c|c|c|c|c|}
\hline 35 & $\begin{array}{l}\text { Petersson, K., Olsson, U. } \\
\text { \& Popekewitz }\end{array}$ & 2007 & $\begin{array}{l}\text { Sweden, } \\
\text { USA }\end{array}$ & $\begin{array}{l}\text { Qualitative } \\
\text { study, } \\
\text { descriptive }\end{array}$ & $\begin{array}{l}\text { Document } \\
\text { studies }\end{array}$ & $\begin{array}{l}\text { Qualitative } \\
\text { study, } \\
\text { descriptive }\end{array}$ & Medium & $\begin{array}{l}\text { Mental } \\
\text { images }\end{array}$ \\
\hline 36 & Dahström, M. & 1995 & Norway & $\begin{array}{l}\text { Quantitative, } \\
\text { descriptive }\end{array}$ & Surveys & $\begin{array}{l}\text { Content } \\
\text { Analysis }\end{array}$ & High & Women \\
\hline 37 & $\begin{array}{l}\text { Lendahls Rosendahl \& } \\
\text { Rönnerman }\end{array}$ & 2007 & Sweden & $\begin{array}{l}\text { Qualitative } \\
\text { study, } \\
\text { descriptive }\end{array}$ & Interviews & $\begin{array}{l}\text { Content } \\
\text { Analysis }\end{array}$ & Low & $\begin{array}{l}\text { Mental } \\
\text { images }\end{array}$ \\
\hline 38. & $\begin{array}{l}\text { Dimenäs, Kolback, Wede } \\
\text { \& Norlund }\end{array}$ & 2013 & Sweden & $\begin{array}{l}\text { Qualitative } \\
\text { study, } \\
\text { descriptive }\end{array}$ & $\begin{array}{l}\text { Documents, } \\
\text { field notes, } \\
\text { reports }\end{array}$ & $\begin{array}{l}\text { Content } \\
\text { Analysis }\end{array}$ & Medium & $\begin{array}{l}\text { Mental } \\
\text { images }\end{array}$ \\
\hline
\end{tabular}

\section{Copyright Disclaimer}

Copyright for this article is retained by the author(s), with first publication rights granted to the journal.

This is an open-access article distributed under the terms and conditions of the Creative Commons Attribution license (http://creativecommons.org/licenses/by/3.0/). 